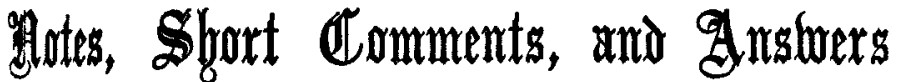 to Cortespondents.}

\author{
KNOWLEDGE AND UNDERSTANDING.'
}

By W. D. Halliburton, M.D. Lond., F.R.S. PROFESSOR OF PHYSIOLOGX, KING'S COILEGE, LONDON.

THE question, "What is Truth?" is likely to remain unanswered for many generations to come, if not for ever. Within the last year or two it has acquired new meaning in the discussions which have contred around the question of relativity so prominently brought before the scientific world by the researches of Einstein. I have not the special mathematical knowledge to pronounce judgment on Einstein's work ; but so far as an outsider has been able to riasp its significance one may briefly say that it has been found that the old Newtonian laws regarding gravitation and the propagation of light have been found not immutable or even absolutely correct in detail, but are only relatively true at a given time in certain conditions of space. In the light of uncertainty regarding the fundamental laws of the physical universe, who can hope, in branches of science dealing with living things, to attain to perfect knowledge? The seekers after truth need not be discouraged, for they will often be rewarded with sufficient understanding to grasp some of its meaning and even to apply the latter to the good of mankind.

\section{Astronomy and Chemistry.}

The old laws of the physical world may not be flawless, but they have enabled astronomers to foretell eclipses with exactitude, to give us the Nautical Almanac with accurate information about the tides and numberless other data, to detect the existence and predict the appearance of new planets, and numerous other feats. In chemistry, the atomic theory is, I suppose, only relatively true. Certainly no one has ever seen an atom, still less the electrons which make up the atoms ; nevertheless, such theories have played an overwhelmingly useful rôle in the progress of chemistry and physics ; witness, for example, the prediction of the discovery of new elements, and the invention of new methods in the application of radiant energy for the alleviation of suffering.

\section{Physiology and Medicine.}

Coming now to the biological sciences, I shall feel more at home when I single out physiology for comment. The relationship of physiology to medicine is one on which I am never tired of dilating. I remember a time which succeded that when anatomy and physiology were taught by the same professor, when physiology was regarded almost as an ornamental extra in most-schools-being taught by a lecturer who was not a trained physiologist and had no idea of research-and when the physiological laboratory was all but non-existent. With the foundation of laboratories the professed physiologist came into being and by diligent work made discovery after discovery. But with a few brilliant exceptions the clinical observer and the laboratory worker seldom came together, and both physiology and medicine suffered in consequence. From this state of things we are now emerging; physicians are beginning to recognise that physiology is the corner-stone of medicine, and that medicine is or ought to be applied physiology. I look forward to a time when clinical teachers will, as a result of laboratory training and experience, have grasped the spirit of research and be able to teach medicine in this spirit of understanding. I do not say we have not such teachers now, but the future will, I am sure, give us many more.

\section{Empiricism in Medicine.}

Medicine is often wrongly reproached for its empiricism, but empiricism is the result of past experience. The reproach is only deserved when medical men elect that their studies shall remain empirical and do not discover causes and reasons. Take, as examples, some morsels of dietetic advice which are often heard from practitioners. (1) In a case of malnutrition take more fat, but preferably in the form of cream or cod-liver oil instead of olive oil or inargarine; (2) in a case of high blood pressure abstain from the red meats, but take fish and poultry ; (3) in a case of obesity take toast, but not bread, and reserve drink till the end of the meal.

The physiological explanation of the first piece of advice is now known, for the useful fats are those which contain the iecently discovered essential accessory factor or vitamin.

Being the substance of an inaugural address delivered before the Midland Medical society, Birmingham, on Nov. 2nd,
Time may show that the second and third are justifiable some little thing, quantitatively small, but qualitatively allimportant, may yet be found to constitute the difference between harmful and useful foods. When such a happy time arrives, when the doctor can give physiological reasons for the faith that is in him, shall we even then be nearer the absolute truth. We may have by then advanced a few steps, but that does not mean we should hesitate to push on. Increase of understanding at least will follow, and with it decrease of suffering and disease.

Enzymes.

We hear a great deal about the activity of enzymes or ferments. It is immaterial that a ferment may be an actual entity or a special phase of matter; ferment action is the great mechanism in the chemical and metabolic activity of the body. This fact is indisputable, although no physiologist has ever seen an enzyme in a state of purity, just as no chemist ever saw an atom, and recently acquired knowledge of the whole subject of immunology is in the same position. We talk glibly of antitoxins, agglutinins, precipitins, opsonins, anaphylactins, hæmolysins-names which are merely the result of a desire to crystallise theories in terms of speech. Such excursions of the imagination may not come into the domain of exact knowledge, but vaccination-a purely empirical procedure in Edward Jenner's day-and have enabled practical men to devise corresponding means for the prevention or cure of other diseases.

\section{Vitamins.}

To turn to a subject already alluded to-namely, the vitamins. Hopkins compared them to the nails and cement in the building of a house; McCarrison compared them to the spark which makes the energy of the fuel effective in a motor-car. Such similes do not add to our knowledge, but they help our understanling; the vitamins are still unknown chemically, but has their study been useless? From the imperfect knowledge at present available immense benefit to mankind has already ensued in the matters of properly balanced diets and of the deficiency diseases in which absence of vitamins plays so imvortant an atiological rôle.

\section{Permeability.}

We owe to physiology many other conceptions beside those of enzymes and vitamins which have profoundly influenced all branches of medicine. Physical chemistry, for example, in physiological hands is one of these. A study of such questions as colloids, surface-tension, and permeability is not only of intense interest in itself but has done much of recent years to place the phenomena of life on an intelligible basis. From the wide field here opened up I will content myself with one example - namely, permeability a subject to which my friend, Prof. H. J. Hamburger, of Groningen, has devoted a life of research. He began with red blood corpuscles, and then passed on to a study of secreting cells. The usual way of explaining the action of a secreting cell is to say that it has a selective action; on one side it is bathed with a nutrient fiuid originating from the blood At its opposite border it pours out a new fluid, we will say saliva. The statement that the cell selects from the lymph certain materials and rejects others implies that the cell has something akin to consciousness and choice, a vitalistic view which cannot commend itself to any lover of exact science. The passage of substances through cells and their membranes is regulated by various physical forces, such as filtration, diffusion, and osmosis, but these alone will not explain all the facts; the subterfuge introduced by the assumption of vital or selective activity is a mere confession of ignorance. Investigation of the permeability of the protoplasmic surface and its membrane has done much to enlighten that ignorance; the cell is permeable to some substances and not to others; it has no real choice as to what shall pass and what it prevents from passing. It has been proved further that different ions modify in various directions the normal permeability; hence the electric charge of the ions must be an important factor in determining the passage of substances through the cell and its plasmatic membrane. In diseased conditions the normal relationships in the ioric balance is upset and cellular activity becomes abnormal. Electric charge is one factor, molecular size is possibly another, solution affinities, surface-tension, \&c., are others. Without attempting a description of all of these, suffice it to say that they are in the region of exact research and measurement.

$$
\text { Permeability of Cells to Sugar. }
$$

Such considerations may be amplified by a brief allusion of what is known in relation to the permeability of cells to sugar. The sugar of the blood is glucose (dextrose); it is always present in health, but is then entirely contained in the blood plasma; the corpuscles are impermeable to this variety of sugar except in that pathological state we call diabetes, where the normal permeability is deranged. That 
this is not governed by the mere size of the glucose molecule is evident when we go to the kidney, for in health the renal cells are also impermeable to glucose, and it is not until normal conditions are upset in diabetes that the kidney cells allow this sugar to pass into the urine. Nevertheless, sugars with larger molecules, such as cane sugar or lactose, if introduced into the blood stream find their way out into the urine even in health. The sieve theory will thus not hold here, so recourse must be had to the "lock and key" hypothesis introduced by Emil Fischer to help us to understand the specific action of enzymes, and which has proved so useful also when one has to deal with questions of specificity in antitoxic and analogous phenomena. The chemical configuration of sucrose is such that it fits the molecular structure of the parts of the cell it penetrates; it can unlock the door and get through; glucose has a different configuration; it cannot open the door so long as the barrier or lock remains healthy. I have taken this to illustrate one of the many features of physiological advance in knowledge, which is of intimate importance to pathology, but even here, after a certain point it is necessary to have recourse to a theory or a useful simile.

\section{Hormones.}

There are many other examples of physiological advance I am tempted to press upon you, but I will be content with only one more-that of the chemical messengers or hormones, of which the discovery has been of incalculable benefit to the practitioner. the blood to minister to parts elsewhere has shed a light on many obscure maladies, as well as on the prncesses of the healthy body. It is true we have a general conception of the way the endocrine organs work and of what happens when the work is badly done, but up to the nresent there are only two of these hormones which are known to us in the true chemical sense-to wit, adrenaline, the secretion of the suprarenal medulla, and thyroxin, the iodine complex was no mean feat and has provided us with a useful drug. When the internal secretion of the adrenal cortex is discovered one may anticipate rational and successful treatment of Addison's disease.

It is necessary to blend newly acquired knowledge with the saving virtue of common-sense. The premature assumption of the truth of various theories is not only inimical to the progress of the science of medicine but may be an actual danger to the community of patients. What cruelly false hopes were raised in the breasts of sufferers when, in the early days of radiology, radium was vaunted as the cure for all or nearly all of our ills, cancer included.

Psycho-Analysis and Spiritualism.

This special evil of the unwisdom of accepting unproved theories, or partially tested cures, is most pronounced when one has to deal with a subject on which our knowledge is scantiest-namely, the action of the mind. I have neither friends nor enemies among the psycho-analysts, so that what I am saying now is entirely impersonal. When speaking of psycho-analysis to medical men I have sometimes been answered in this way. "After all, there are some good psycho-analysts; Dr. So-and-So, for example, gains the confidence of his patients, gives them good advice, and comforts them; he even knows a little neurology." Is not this damning him with faint praise? Any good doctor, psycho-analyst or not, can win, or should win, his patients' confidence and thus benefit them.

Whatever view one may hold as to the value of psychoanalysis in the treatment of so-called functional disorders, there can be no difference of opinion that any attempt to attack organic disease by its agency should at once be authoritatively condemned. Yet I see in an American journal of repute an attempt in this direction on the part of a qualified doctor of medicine; he proposes that multiple sclerosis should be so treated. At first one took the article to be satirical, but it is quite evident that it is intended seriously. In all ages we see at intervals instances of charlatanism making inroads into the region of exact knowledge and delaying its progress. The war has been blamed for present tendencies in this direction; the war may have exacerbated the condition of mental unrest, but did not cause it. To condemn spiritualism with its many ramifications as a delusion or as humbug, and its professors as deceivers or deceived may be correct, but it is not argument. I should like to see the appointment of a responsible committee made up of physiologists, medical men, physicists, profes sional conjurers, the spiritualists themselves, together with a certain number of unbiassed public men gifted with common-sense, to investigate it by the cold light of exact experiment, and to report upon the claims of the occultists. As the matter stands at present, the practices of believers in the supernatural can only exaggerate the mental unrest to which I have alluded; moreover, if the statements of one party are ignored, many will conclude that the other side has nothing to say - as they concluded in the antivivisection controversy.

In conclusion, progress in the scientific foundation of medicine depends on accurate observation, experiment, and reasoning combined with imagination which must not be unbridled. True knowledge and understanding suffer from the absence of one or more of these essential attributes of progress. To recognise and guard against the pitfalls of half-knowledge is the only way to avoid them.

\section{INSTITUTIONAL CONVALESCENCE.}

Is a pamphlet entitled "Convalescent Care for an American City of One Million Population " and reprinted by permission of the Cleveland Hospital Council, Dr. Frederic Brush (Medical Director, the Burke Foundation, White Plains, N.Y.) sets forth a scheme for utilisation of that period of convalescent when recuperative rest may be favourably combined with mental and moral rehabilitation of the patient. Dr. Brush begins with the statement that the patient's home is usually the best place for convalescence, but that institutional accommodation is necessary in a proportion of cases ; this proportion he sets at 10 per cent. of all hospital cases, with an additional fifth of that 10 per cent. to include patients from dispensaries and other sources. Assuming the city in question to present fair living conditions, a figure of 5000 hospital patients, plus 1000 from other sources, is taken as a planning basis. The average stay in American convalescent homes has been proved to be about 21 days; thus the 6000 patients require 350 beds.

Allotment of Beds.

An estimate based upon the experience of the institutions in great cities apportions beds as follows: (1) In a main institution for adult men and women of all ages from 15 upwards, 120 beds, including 15 per cent. or more cases of heart disease, together with cases undergoing preventive treatment, standard surgical cases requiring dressings, and cases of " chronic handicapped" convalescence; (2) in a children's home, 100 beds, for girls aged $6-15$, and boys aged $6-10$, including orthopædic and surgical dressing cases, and heart disease up to 20 per cent. of the total, with the above-named "standard lines" in addition ; (3) in a boy's place, 30 beds, for ages $10-15$, with disease classification as in the children's home ; (4) in a section for mothers with infants and young children, 30 adult beds, averaging 60 patients ; (5) in a special heart institution, for the seriously. ill but probably restorable cases, 40 beds, for ages and seses as in the children's home.

\section{The Cost of Housing.}

New or expensive buildings are described as inessential An old mansion, a large farmhouse with out-buildings, or a disused hotel may readily be adapted. Tents will serve on occasion ; extensions are easily made and much equipment may be improvised. Five acres of land is the minimum. The various homes might occupy one large plot of 100 acres if the necessary separation of patients could be ensured. A site within 20 miles of the centre of the city is desirable for purposes of transport, coöperation of staff, \&c. A daily cost of $\$ 1.75$ to $\$ 2.00$ per head might be expected, giving approximately $\$ 225,000$ as a minimum yearly working cost for the 350 beds, ineluding transport and maintenance of a city admission office. The selection of patients would be performed by one (possibly part-time) city officer, and the necessary work of following up of cases, including vocational and occupational direction, might be done by the city organisations which sent patients.

\section{Some Details.}

Dr. Brush explains that preventive tuberculosis, convalescent orthopædics, and bone diseases are included under (1), (2), and (3) above; that cardiac children well enough for reconstructive graduated exercise treatment are provided for under numbers (2) and (3); that adolescents (the group most successfully dealt with and yet most neglected in convalescence) are especially considered.

As interest grows," he writes, "and convalescent experience matures, the extensions of this service. will probably be towards separate provision for orthopædics, pay convalescents, the coloured, and for the various border-line, nervous, and mental patients, who everywhere lack long-term preventive and convalescent opportunity."

Prevention, education, refinement, and Americanisation, occupational adjustment, vocational direction, re-encouragement," are stated to be the objects of Dr. Brush's system. "Such an institution .... . would serve to stimulate medical study of convalescence, now a field much neglected, and would promote throughout the community interest in the problem of convalescence which will add to the efficiency of all kinds of medical care in hospitals, dispensaries, and in the home." 
QUEENSLAND HOSPITALS FOR THE INSANE.

THE general report of the Inspector of Asylums for 1920 contains the following details of the mental hospitals and reception houses in the State. On Jan. 1st, 1920, there were 1738 males, 981 females, total 2719 persons certified as insane in the State. During the year 318 males and 180 females were admitted into the mental hospitals, of whom 265 males and 141 females were admitted for the first time, while 53 males and 39 females, or $18 \cdot 47$ per cent., were re-admissions, as compared with 18.57 per cent. during the previous year. From the mental hospitals 145 patients were discharged recovered, and from the reception houses 41 . The discharged recovered, and from the reception houses $49 \cdot 16$ males, $54 \cdot 73$ females, $51 \cdot 99$ total per cent. for all the mental hospitals and reception houses in the State. This result is extremely satisfactory. for a number of recoveries take place in the mental ward of the Brisbane General Hospital of mental cases that have not been certified, and therefore are not included in the above figures. In addition to those discharged recovered, 19 males and 9 females were discharged to the care of their friends and relatives relieved or not improved. During the year, 129 males and 65 females died in the mental hospitals and reception houses, the death-rate being $7 \cdot 40$ males, $6 \cdot 69$ females, total $7 \cdot 15$ per cent. of the average numbers resident.

The numbers remaining in all the mental hospitals and reception houses at the end of the year were 1746 males, 901 females, total 2697 , in addition to whom 26 males and t0 females were out on leave of absence ; so that there were 1772 males, 992 females, total 2764 , on the books certified as insane in the State. These figures show an increase of 34 males, 10 females, total 44 on those of the previous year. The proportion of the insane in 1920 was 3.74 per 1000 of the population (males $4 \cdot 61$, females $2 \cdot 79$ ).

The lectures, demonstrations, and practice papers have been given to the nurses and attendants during the past year at all three mental hospitals in accordance with the regulations laid down by the State Nurses' Registration Board. The nursing staffs at the three mental hospitals at present are: Goodna, 132 attendants, 96 nurses; Toowoomba, 64 attendants, 85 nurses; Ipswich, 57 attendants, 48 nurses ; making a nursing staff total of 482 .

AN OUTLINE OF SCIENCE.

Messrs. George Newnes are bringing out in fortnightly parts an "Outline of Science," edited by Prof. J. Arthur Thomson, following on the lines of Mr. H. G. Wells's wellknown outline of universal history. The general aim of the outline is to help the reader to get a clear and concise view of the state of present-day science in order that he may be able to follow with intelligence the modern advances and to share appreciatively in man's continued conquest of his kingdom. To middle-aged and middle-aging people who keep in the running of domestic affairs and politics it will come as a surprise to see how the discoveries of men like J. J. Thomson, Ernest Rutherford, and Frederick Soddy have made archaic their childhood's conception of dead or inert matter. The electron theory is, indeed, only just beginning to show us what electric phenomena actually mean. Similarly, the discovery of hormones at the hands of men like Starling and Bayliss is changing the whole face of physiology. If Prof. Thomson succeeds in bringing home to a large circle of readers a lively knowledge of these things he will have performed a great service to his generation. Part I. contains the Romance of the Heavens and the beginning of the Story of Evolution. The illustrations are striking and on the whole well chosen, although the photographs of planets are curiously woolly, and it is difficult to think of a view point in space to justify the pictorial representation of the solar system on p. 16. Such popularisation of science is in harmony with the effort of the Selborne Society, to which Mr. W. M. Webb, F.L.S., calls attention in a following letter.

THE SELBORNE SOCIETY AND CINEMATOGRAPHY. To the Editor of THE LANCET.

SIR,-In a letter which I wrote during the summer I mentioned that the Selborne Society was interesting itself in cinematography. The time has evidently come when an endeavour should be made to take advantage once more of what we may call non-theatrical films. There are many matters in connexion with science generally and natural history in particular, with customs, history, and travel which interest a large proportion of the public.' The Society is beginning by introducing films into its extension lectures, one of which, with the help of travelling motor lorries carrying projection apparatus, can now be given anywhere in the country. It is forming a cinematography committee with the object of introducing more films of the sort which we have described into the cinema halls, to arrange entertainments where theatrical films are in the minority, to build up a film library, and, when prices of apparatus and films allow, to introduce the cinematograph into the ordinary curriculum of schools.
Sir George Aston and Sir Gilbert Parker have signified their intention of joining the committee, which already includes the following: Lieut.-Colonel E. S. Amery, M.P. Sir W. Watson Cheyne, M.P., Capt. W. E. Elliott, M.P.,
Mr. Joseph Hood, M.P., Mr. R. B. Frere, Sir Sidney Low, Mr. Oswald Mosley, M.P., Mr. Leslie Scott, K.C., M.P., Sir Ernest Wild, K.C., M.P.

I hope that any of your readers who are able to help in any way will communicate with me.

I am, Sir, yours faithfully,

The Hermitage, Hanwell, w. 7 , Nov. 19th, 1921

\section{AN ANCIENT SCOTTISH HAIR-CAST. \\ To the Editor of THE LANCET.}

Sir,-Mr. Alfred Ela, of Boston, U.S.A., has written calling my attention to an omission from the bibliography of my article on Hair-Casts which appeared in THE LANCE' of Oct. 15th. Mr. Ela's contribution was to the Boston Medical and Surgical Journal in March, 1918, and ran as follows :-

Review in Archeological Journal, 1916, 1xxii., 402, of Banff Charters, A.D. 1232-1703, viz., Oct. 9th, 1232, lands ' were granted to Master Neis, the King's Physician, by Alexander II.'; Neis 'is reported to have obtained this reward for While the service seems shadowy, the fee was substantial."

I am, Sir, yours faithfully,

Cardiff, Nov. 9th, 1921. IroR J. DAVIES.

\section{CYNOTHERAPY.}

To the Editor of THE LANCET.

SIR,--In reply to Dr. W. J. Rutherford (THE LANCET, Nov. 12th, p. 1038) I enclose a recipe for dog oil copied from Pharmacopoia Londinensis, date 1659 , by "Nich. Culpeper, Gent., Student in Physick and Astrology." The book contains the name of an old owner thereof, thus : "Peter Reid, Senor. His book. Trafalger."

I am, Sir, yours faithfully,

VERE G. WEBB, M.R.C.P.I.

Haverstock-hill, N.W., Nov. 16th, 1921.

Enclosure.

Olfum CATELIORITM 146, oR, OIL OF Whelps.

Colledg.-Take of Sallet oyl four pound, two Puppy dogs newly whelped, Earth worms washed in white wine one pound; boy the whelps till they fall in pieces, then put in the worms, a while after strain it, then with three ounces of Cypress, Turpentine, and one ounce of spirit of Wine perfect the oyl according to art. Muscles that have been weakened by wounds or bruises.

THE LATE COLONEL A. B. R. MYERS'S AUTOPHLEBOTOMY.

To the Editor of THE LANCET.

SrR,-In your obituary notice (August 13th) of the late Colonel Myers no mention is made of his authorship of " Life with the Hamran Arabs "- -an interesting book describing a sporting trip in the Soudan in the year 1875. It contains an incident of particular medical interest-viz., the performance of autophlebotomy (pp. 282-3). Having been prostrated with intense headache and nausea for several days as a result of sunstroke, he thought that blood-letting would do him good. As he had no European companion present at the time to perform the operation he was obliged to do it himself. He first opened a vein in his left arm, but this was ineffectual; he then did the same in the right arm and was successful in causing a flow of $8 \mathrm{oz}$. of blood. This caused some immediate faintness but procured the desired relief. In bygone days, when venesection was practised frequently and was better understood than it is now, the performance of it by a medical man on his own corpus vile may have happened occasionally, but I think that it must be very uncommon. I cannot remember any case recorded in literature.

I am, Sir, yours taithfully, F. LuCas BenhaM, M.D., M.R.C.P.

Exeter, South Australia, Oct. 5th, 1921

\section{PUBLIC HEALTH IN HONG-KONG.}

A REPORT for the year 1919, prepared by Mr. A. G. M. Fletcher, Colonial-Secretary, estimates the total civil population at 598,100 , including 13,600 non-Chinese. The birth-rate for the year was 3.9 per 1000 among the Chinese community and 20.6 per 1000 among the nonChinese, as compared with $3 \cdot 6$ and $22 \cdot 1$ in 1918. The death-rate was 23.3 per 1000 among the Chinese and $19 \cdot 9$ among the non-Chinese, as against 29.6 and 19.5 in the previous year. The number of deaths from malaria (310) showed a decrease. In the City of Victoria the deaths of Chinese from this cause numbered 101 out of a population of 320,080 , or a rate of 0.3 per 1000 per annum. The deaths from plague numbered 426 , as compared with 251 in 1918. Small-pox deaths numbered 15, all Chinese. 
There were 3049 deaths from respiratory diseases, and 1545 from various forms of tuberculosis. Beri-beri was responsible for 555 deaths, as compared with 804 in 1918 and 654 in 1917. During the past few years circulars have been distributed to all large employers of coolie labour calling their attention to the fact that beri-beri is produced by the consumption of white rice as the staple article of diet without a sufficiency of other foods, and advising that beans should be supplied with the rice when fresh meat or fresh fish cannot be afforded.

Government hospitals consist of the Civil Hospital, to which is attached an isolated maternity hospital, the Victoria Hospital for Women and Children, and the Kennedy Town Infectious Diseases Hospital. There is an observation station capable of accommodating 1500 persons in the event of an outbreak of infectious disease on board a ship arriving in the harbour. In the Civil Hospital, which contains 166 beds in 20 wards, 3926 in-patients and 22,446 out-patients were treated during $1919 ; 218$ cases of malarial fever were admitted ; 460 confinements occurred during the year in the Maternity Hospital, which contain 12 beds for Europeans and four for Asiatics; 54 infectious cases were treated at the Kennedy Town Hospital. In the Lunatic Asylum 207 patients of all races were treated, and there were eight deaths. The Tung Wa Hospital, which is mainly supported by the voluntary subscriptions of Chinese, receives an annual grant from the Government. Only Chinese are treated in this institution, which performs other services as well as those appertaining to a hospital such as the free burial of the poor, the repatriation of destitutes, and the organisation of charitable relief in emergencies. Chinese as well as European methods of treatment are employed in accordance with the wishes expressed by the patients or their friends. About half the number are now treated by Western methods. The hospital is managed by a committee of Chinese, who are annually elected. It is under the supervision of a visiting physician, who is a member of the medical department whilst two Chinese house surgeons, trained in Western medicine, are members of the hospital staff. There are 323 beds in the buildings, and 7002 patients were accommo323 beds in the buildings, and 7002 patients were accommo-
dated during 1919 . The Tung $\mathrm{Wa}$ also maintains a branch hospital for small-pox cases (Chinese only). It contains 58 beds, and during 1919 four cases were treated.

The Alice Memorial and Affiliated Hospitals are managed and controlled by the missionaries resident in Hong-Kong agents of the London Missionary Society. The number of in-patients in 1919 was 1395 . To avoid the complete seclusion from friends and relatives which removal of Chinese plague patients to the Kennedy Town Infectious Hospital entailed, four District Plague Hospitals are maintained by the Chinese in various parts of the colony. The new Kwong Wa Hospital for Chinese in the Kowloon Peninsula was opened in 1911. There are $70 \mathrm{beds}$, and 3313 patients were accommodated during 1919.

The University of Hong-Kong is an institution that arose from the joint enterprise of British and Chinese subscribers. At the end of 1919 the number of students was 225 , of whom 75 were taking the medicine course. The idea of the University is to provide, close to China, education similar to that given in the British universities, but at a much cheaper cost. The medical faculty offers ample facilities for the practice of medicine. The medical laboratories were the gifts of various Hong-Kong Chinese residents. There is a large staff of instructors in medicine, and all the principal medical practitioners in Hong-Kong give lectures at the University. Clinical work is carried on at the Government Civil and Tung Wa Hospitals. The degrees are recognised for registration in Great Britain by the General Medical Council. The University insists upon all students having a proper knowledge of their own language, although

The mean temperature for the year 1919 was $72.2^{\circ} \mathrm{F}$. as against $71.2^{\circ}$ in 1918 , and $71.8^{\circ}$ for the past 36 years. The total rainfall for the year was $76 \cdot 140$ inches, as against 101.605 inches in 1918, and 83.620 inches for the past 36 years. The climate of Hong-Kong is similar in its broad features to that of Kowloon and the New Territories, but at the higher levels, from 1400 to 1800 feet above sea-level, the temperature is usually from $3^{\circ}$ to $6^{\circ}$ lower than at the Observatory, Kowloon. The humidity is usually greater than in Kowloon, and approaches saturation for several days at a time during March and April, when mist is very prevalent. In summer the City of Victoria and the rising terraces behind it derive little or no benefit from the south-west monsoon, being sheltered by steep hills from S.E. to S.W. In winter it is exposed to the north-east monsoon, which occasionally blows along the harbour, through Lyemun Pass, with considerable violence. On the other hand, the south-west side of the island is protected from the north-east monsoon in winter, and enjoys the benefit of the south-west monsoon in summer.
RXCESSIVE PRESCRIBING.

$A$ PuAcTrTIONER was recently asked by his panel committee to justify two prescriptions each containing 6 oz. of Stokes' liniment (Lin. album). TIis chief concern was the unreasonable cost of this prescription, which was charged at $9 \mathrm{~d}$. for the liniment and $4 d$. for the dispensing fee. This pricing i in accordance with the official tariff and cannot, of course. be altered until this tariff is modified by the fall in the cost of drugs. The criticism of the panel committee was directed to the amount ordered on one prescription. It wai considered that this quantity would be wasted, and that $2 \mathrm{oz}$. or at most $4 \mathrm{oz}$, was sufficient to order on one occasion. Only in exceptional cases would it be necessary to use more than $4 \mathrm{oz}$. of liniment in a week. The cost may appear a trifling matter in one or two cases, but considering the vast number of prescriptions given in one area the total amount may be a serious and unnecessary drain on the drug fund which is provided by the Treasury out of public money.

\section{TO VENTILATE AND DEODORISE.}

THE "Win-Sum" radiator, recently patented by Messrs. Tidd, Siday and Co., Ltd., of 180, Drury-lane, London, W.C. is a combination of an electric radiator and ventilating fan. The radiator forms the front of a box in which the metal fan is placed. Air is drawn into the apparatus and forced through the four porcelain and wire " elements," each of which can be turned on by a switch, thus regulating the degree of heating of the air. The manufacturers claim that the consumption of two electrical units an hour by this apparatus produces a uniform temperature of $60^{\circ} \mathrm{F}$. on cold days in a room $20 \mathrm{ft}$. by $20 \mathrm{ft}$. by $12 \mathrm{ft} .6 \mathrm{in}$. In summer the agitation of the indrawn air and its subsequent distribution throughout the room by the agency of the revolving fan produces a cooling effect. The box-like apparatus is placed on the floor of the room near the door ; it is especially intended for use in ordinary rooms of houses but can also be employed to disperse the pockets of stagnant air not infrequently found in certain parts of the "auditorium " of kinemas and other places of public entertainment. Slabs of absorbent porcelain material, to be soaked in eucalyptus or other volatile antiseptic, are provided in order that various odours may be added to the air forced through the radiator. The cost of the radiator is $£ 20$ retail.

\section{CENTRAL HEATING IN CHICAGO.}

A $T$ the beginning of another winter and with coal at its present price it is of interest to note how the question of cold dwelling houses for the people is dealt with in foreign countries. A copy of the "Bulletin of the Chicago School: of Sanitary Instruction," now before us, suggests at the first glance that in that city landlords in general are compelled by the sanitary authority to supply heat to their tenants. on the ground that otherwise a building is being maintained by them in a manner dangerous to health. It is to be gathered, however, from closer study of the article that at Chicago a large number of buildings divided into separate tenements are constructed in a manner which has been recommended here as desirable from the point of view of United Kingdom as far as we are aware. In Chicago the rooms in question have no source of heating, except that which is under the control of the landlord; although they are, or can be, supplied with gas apparatus sufficient for cooking. Chicago landlords, it is stated, are, as a rule,. compellable by the terms of their leases to supply heating to their tenants, who can sue them for breach of contract. Where such covenants do not exist, or possibly where they do, the sanitary authority is prepared to act in the interest of the citizens. At present, as we have said, no such most of the rooms is most of the rooms let as living rooms are warmed by open fires
or gas stoves. The flats, in London at all events, which are centrally heated, are lived in by tenants who are well able to enforce the terms of their leases. The experience of Chicago, however, may point to the desirability of considering the welfare of the tenant of working-class tenements, if and when any are constructed in such a way that the dwellers in them are dependent entirely upon the landlord for. warmth in cold weather. It may, in other words, be desirable when any such buildings are erected to make it the duty of a public authority to see that they are sufficiently warmed to. be safely inhabited. Tenants of the humbler class do not take leases with elaborate covenants, and often hold their rooms on such terms that they are not lilsely to bring their: landlords into court.

$C . B . W$. has put his finger upon defaults that are commont to every form of professional education. We are afraid that the medical profession would not welcome an examination in middle age to see whether a proper standard of knowledge was still being maintained. 